\title{
Energy Yield of Denitrification: An Estimate from Growth Yield in Continuous Cultures of Pseudomonas denitrificans under Nitrate-, Nitrite- and Nitrous Oxide-limited Conditions
}

\author{
By I. KOIKE AND A. HATTORI \\ Ocean Research Institute, University of Tokyo, Nakano, Tokyo I64, Japan
}

(Received 25 July 1974; revised 30 November 1974)

SUMMAR Y

The molar growth yields of Pseudomonas denitrificans, for nitrate, nitrite and nitrous oxide, were determined in chemostat culture under electron acceptorlimited conditions. Glutamate was used as the source of energy, carbon and nitrogen. The catabolic pattern was identical, irrespective of the terminal electron acceptors.

The molar growth yields, corrected for maintenance energy, were $28.6 \mathrm{~g} / \mathrm{mol}$ nitrate, $16.9 \mathrm{~g} / \mathrm{mol}$ nitrite and $8.8 \mathrm{~g} / \mathrm{mol}$ nitrous oxide. The energy yield, expressed on an electron basis, was proportional to the oxidation number of the nitrogen: nitrate $(+5)$, nitrite $(+3)$ and nitrous oxide $(+1)$. It was concluded that oxidative phosphorylation occurs to a similar extent in each of the electron transport chains associated with the reduction of nitrate to nitrite, nitrite to nitrous oxide and nitrous oxide to nitrogen.

\section{INTRODUCTION}

In the denitrification performed by Pseudomonas denitrificans and P. perfectomarinus, nitrate is reduced stepwise to nitrogen gas via nitrite, nitric oxide and nitrous oxide as intermediates (Barbaree \& Payne, 1967; Matsubara \& Mori, 1968; Miyata \& Mori, I968; Payne, Riley \& Cox, 1971).

Phosphorylation coupled to nitrate reduction to nitrite has been demonstrated in Micrococcus denitrificans, $P$. denitrificans and $P$. aeruginosa (Yamanaka, Ota \& Okunuki, I962; Ohnishi, 1963; Naik \& Nicholas, 1966). Some denitrifying bacteria grow anaerobically with nitrite or nitrous oxide as terminal electron acceptor, suggesting that phosphorylation also takes place coupled to nitrite reduction to nitrogen gas (Pascal, Pichinoty \& Bruno, I965; Kodama, Shimada \& Mori, I969; Matsubara, I97I). However, neither the steps nor the sites of coupling of electron transport in the reduction of nitrate with phosphorylation have been determined.

The energy yielded by $P$. denitrificans denitrification is about half that of aerobic respiration (Koike \& Hattori, 1975). The low efficiency of denitrification can be explained by the lack of oxidative phosphorylation in certain step(s) of denitrification and/or by a reduction in the number of phosphorylation sites in the electron transport chains associated with denitrification.

The present study examines which steps of the denitrification sequence are coupled to oxidative phosphorylation and the energy yield in the electron transport chain associated with each step in the reduction of nitrogenous oxides. $P$. denitrificans grows well with nitrate, nitrite or nitrous oxide as terminal electron acceptor. The growth yields per mole of terminal electron acceptors reduced were used as an index. 


\section{METHODS}

Organism. Pseudomonas denitrificans was isolated from the bottom mud of a brackish lake (Koike \& Hattori, 1975).

Culture media and conditions. The mineral components of the medium were those used in the previous study (Koike \& Hattori, I975), except for $\mathrm{KNO}_{3}$. Glutamate (I2 mM) was used as carbon, energy and nitrogen source. The organism was grown in a chemostat with limiting terminal electron acceptor of $\mathrm{ro} \mathrm{mM}-\mathrm{KNO}_{3}$ or $-\mathrm{NaNO}_{2}$.

Anaerobiosis was maintained by bubbling argon $(50 \mathrm{ml} / \mathrm{min})$ through the medium. When nitrous oxide was used, the argon was replaced by a mixture of $10.3 \%$ nitrous oxide and $89.7 \%$ argon (Takachiho Co., Tokyo). The flow rate was kept constant with a peristaltic pump at values from $5.8 \mathrm{ml} / \mathrm{min}$ at dilution rate $(D)=0.05$, to $8.5 \mathrm{ml} / \mathrm{min}$ at $D=0.1 \mathrm{I}$, and checked daily. To eliminate traces of oxygen, argon was bubbled through the medium in the reservoir at regular intervals.

The culture apparatus and details of procedures are described elsewhere (Koike, 1975).

Determination of molar growth yield. The growth yield $(\mathrm{g} / \mathrm{mol})$ for nitrate, nitrite or glutamate was calculated using the equation:

$$
Y=\frac{x}{S_{1}-S_{0}}
$$

where $x$ is the bacterial concentration (dry weight, $\mathrm{g} / \mathrm{l}$ ) in the medium at steady-state, $S_{\mathrm{i}}$ is the substrate concentration in the feeding medium (mol/l), and $S_{0}$ is the substrate concentration in the culture vessel (mol/l).

The growth yield for nitrous oxide ( $Y_{\mathrm{N}_{2} \mathrm{O}}$, in $\mathrm{g} / \mathrm{mol}$ ) was calculated from the rate of cell production $(\mathrm{g} / \mathrm{l} / \mathrm{h})$ and the rate of nitrous oxide consumption $(\mathrm{mol} / \mathrm{l} / \mathrm{h})$ :

$$
\begin{aligned}
Y_{\mathrm{N}_{2} \mathrm{O}} & =\frac{\text { rate of cell production }}{\text { rate of } \mathrm{N}_{2} \mathrm{O} \text { consumption }} \\
& =\times D /\left(C_{1}-C_{2}\right) \times \frac{273}{T+273} \times \frac{f}{100} \times \frac{\mathrm{I}}{22 \cdot 4},
\end{aligned}
$$

where $D$ is the dilution rate $\left(\mathrm{h}^{-1}\right), C_{1}$ the nitrous oxide content in the feeding gas $(\%), C_{2}$ the nitrous oxide content in the effluent gas corrected for volume change (\%), $T$ the temperature of the gas mixture $\left({ }^{\circ} \mathrm{C}\right)$, and $f$ the flow rate of gas $(1 / \mathrm{h})$.

Analytical methods. Volatile and non-volatile organic acids in the culture media were determined by a Hitachi model $\mathrm{K} 53$ gas chromatograph equipped with a hydrogen flame ionization detector. A $2 \mathrm{~m}$ glass column was used, packed with Chromosorb W on which I0 \% Carbowax $20 \mathrm{M}$ terminated with 2-nitro-terephthalic acid plus $3 \%$ phosphoric acid had been adsorbed (Gaschro Industry Co., Tokyo). The column temperature was $150^{\circ} \mathrm{C}$. Nitrogen was used as the carrier gas. Samples to be assayed were neutralized and concentrated fivefold under reduced pressure. For volatile acids, $\mathrm{I} \cdot 0 \mathrm{ml}$ portions of the concentrated samples were acidified by adding $0.2 \mathrm{ml}$ of $25 \%$ metaphosphate in $5 \mathrm{~N}-\mathrm{H}_{2} \mathrm{SO}_{4}$. Nonvolatile organic acids were methylated by boiling $0.4 \mathrm{ml}$ of the concentrated samples with an equal volume of $\mathrm{I} 4 \%(\mathrm{w} / \mathrm{v})$ boron-trifluoride in methanol for $10 \mathrm{~min}$. The methyl esters were then extracted with chloroform $(0.2 \mathrm{ml})$. Crotonic acid and fumaric acid, for volatile and non-volatile acids respectively, were used as internal standards. These two acids were not present in the original samples.

The concentration of $\mathrm{CO}_{2}$ and $\mathrm{N}_{2} \mathrm{O}$ in the inflow and outflow gases was determined with a Shimazu model GC-3 AL gas chromatograph fitted with a thermal conductivity detector. 
Samples were collected in a gas reservoir ( $40 \mathrm{ml}$ capacity) with two stop-cocks, after first passing $\mathrm{I} 1$ of gas through the reservoir. Portions ( $\mathrm{I} \mathrm{ml}$ ) were introduced at a pressure of I atm by a mercury Toepler pump into the gas chromatograph with a I $\mathrm{m}$ column of Porapak T (Waters Associates Inc., Massachusetts, U.S.A.). Chromatography was carried out at $50{ }^{\circ} \mathrm{C}$, using helium as carrier gas. Since the retention time of $\mathrm{CO}_{2}$ was almost identical with that of $\mathrm{N}_{2} \mathrm{O}$, samples treated with $2 \mathrm{ml}$ of $40 \%(\mathrm{w} / \mathrm{v})$ potassium hydroxide were run simultaneously to correct for $\mathrm{N}_{2} \mathrm{O} . \mathrm{CO}_{2}$ and $\mathrm{N}_{2} \mathrm{O}$ from Takachiho Co., Tokyo, were used as reference compounds. $\mathrm{No} \mathrm{CO}_{2}$ was detectable in the inflow argon gas. The rate of $\mathrm{CO}_{2}$ production was therefore calculated from the concentration of $\mathrm{CO}_{2}$ in the outflow gas and the flow rate as measured by a Roger-Gilmont flowmeter. Correction was made for dissolved $\mathrm{CO}_{2}$ in the effluent medium.

When $\mathrm{N}_{2} \mathrm{O}$ was used as electron acceptor, the Porapak T column was replaced by a $3 \mathrm{~m}$ column of silica gel. Separation of $\mathrm{N}_{2} \mathrm{O}$ from $\mathrm{CO}_{2}$ was satisfactory at a column temperature of $30^{\circ} \mathrm{C}$.

The concentration of NO in the effluent gas was determined mass-spectrometrically as described by Koike \& Hattori (1975).

Nitrate and nitrite were determined by the methods of Wood, Armstrong \& Richards (1967) and Bendschneider \& Robinson (1952), respectively. Other analytical procedures were as described previously (Koike \& Hattori, 1975).

\section{RESULTS}

Molar growth yield for glutamate under electron donor- or acceptor-limited conditions

Using glutamate as sole organic source, growth yields of $P$. denitrificans were compared under the conditions of anaerobiosis and limitation of supply of nitrate, nitrite, $\mathrm{N}_{2} \mathrm{O}$ or glutamate (Fig. I). The specific growth rate changed from about 0.12 (near the maximum specific growth rate, $\mu_{\max }$ ) to about 0.04 . Under anaerobic conditions, nitrate, nitrite and $\mathrm{N}_{2} \mathrm{O}$ supported bacterial growth. The growth yield per mole of glutamate decreased with decrease in the specific growth rate $(\mu)$. The highest growth yield was obtained under glutamate-limited conditions. Complete oxidation of glutamate under glutamate-limited conditions was shown previously (Koike \& Hattori, 1975). The dependence of growth yield on specific growth rates under $\mathrm{N}_{2} \mathrm{O}$-limited conditions differed somewhat from those observed with nitrate and nitrite. The growth yield was invariably higher when growth was limited by glutamate than when limited by the supply of terminal electron acceptors.

\section{Carbon balances under terminal electron acceptor-limited conditions}

Table I summarizes the carbon balances in nitrate-, nitrite- and nitrous oxide-limited growth. Large amounts of glutamate remained in the effluent medium. About half of the glutamate-carbon was oxidized to $\mathrm{CO}_{2}$ and 15 to $20 \%$ was incorporated into cell materials, irrespective of the limiting factors. The rest was accounted for by acetate and succinate. Total recovery was more than $90 \%$.

Under nitrate-limited conditions, the proportion of acetate to consumed glutamate was almost unaltered, irrespective of the specific growth rate (Table 2), whereas the proportion of succinate decreased considerably with increase in specific growth rate. The same trend was observed when nitrate was replaced with nitrite or $\mathrm{N}_{2} \mathrm{O}$ (Table 2). Transient accumulation of acetate in batch culture of $P$. denitrificans under denitrifying conditions using glutamate as substrate has already been reported (Koike \& Hattori, 1975). 


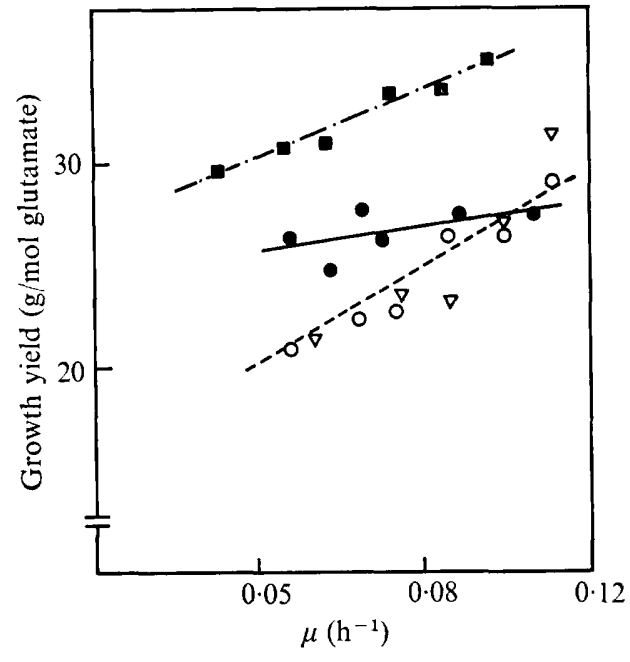

Fig. I

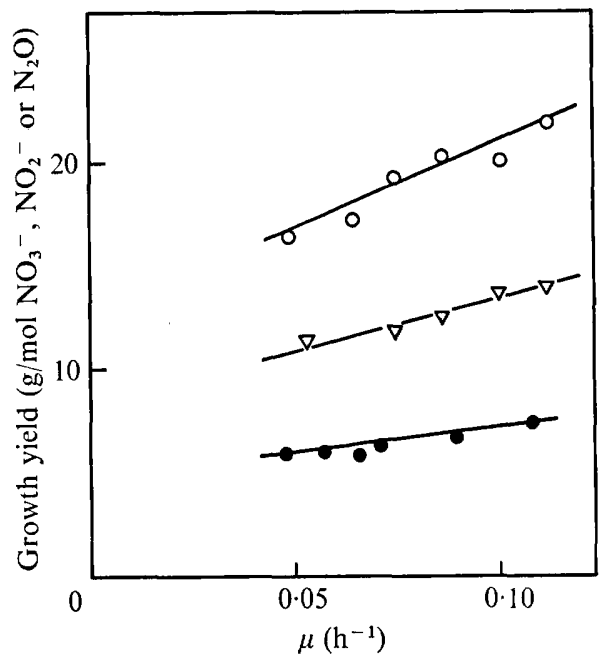

Fig. 2

Fig. I. Growth yield per mole of glutamate of $P$. denitrificans under anaerobic conditions as a function of the specific growth rate, $\mu$. The growth yield with glutamate-limitation is cited from Koike \& Hattori (1975). Culture temperature was $30^{\circ} \mathrm{C} ; \mu$ was obtained from the dilution rate. $\mathbf{\square}$, Glutamate limitation; $O$, nitrate limitation; $\nabla$, nitrite limitation; $\boldsymbol{\bullet}$, nitrous oxide limitation. Fig. 2, Growth yield per mole of nitrate, nitrite or nitrous oxide of $\boldsymbol{P}$. denitrificans under anaerobic conditions as a function of specific growth rate, $\mu$. Culture temperature was $30^{\circ} \mathrm{C} ; \mu$ was obtained from the dilution rate. $\bigcirc$, Nitrate limitation; $\nabla$, nitrite limitation;, , nitrous oxide limitation.

Table I. Carbon balance during the steady-state growth of P. denitrificans under nitrate-, nitrite- or nitrous oxide-limited conditions in the presence of excess glutamate as carbon source

Figures in parentheses represent the ratio of each of the carbon products to consumed glutamate on a carbon basis.

Production or consumption of carbon $(\mathrm{mg} \mathrm{C} / \mathrm{h}$ )

\begin{tabular}{|c|c|c|c|}
\hline \multirow[b]{2}{*}{ Carbon source } & \multicolumn{3}{|c|}{ Production or consumption of carbon $(\mathrm{mg} \mathrm{C} / \mathrm{h})$} \\
\hline & $\begin{array}{l}\text { Nitrate-limited } \\
\quad(\mu=0.049)\end{array}$ & $\begin{array}{l}\text { Nitrite-limited } \\
(\mu=0.053)\end{array}$ & $\begin{array}{c}\text { Nitrous } \\
\text { oxide-limited } \\
(\mu=0.057)\end{array}$ \\
\hline $\begin{array}{l}\text { Inflow } \\
\text { Glutamate }\end{array}$ & 347 & $38 \cdot 4$ & $44 \cdot 0$ \\
\hline $\begin{array}{l}\text { Outflow } \\
\text { Glutamate } \\
\text { Cell } \\
\mathrm{CO}_{2} \\
\text { Acetate } \\
\text { Succinate }\end{array}$ & $\begin{array}{l}\text { II.3 } \\
3.84(\mathrm{I} 7 \%) \\
\text { II.9 (51\%) } \\
2.54(\mathrm{I} \%) \\
4.16(18 \%)\end{array}$ & $\begin{array}{l}2 \mathrm{I} \cdot 5 \\
2.72(16 \%) \\
7.80(45 \%) \\
1.28(7 \%) \\
5.68(32 \%)\end{array}$ & $\begin{array}{l}15.6 \\
5.28(19 \%) \\
16.6(59 \%) \\
I \cdot 32(5 \%) \\
I \cdot 75(6 \%)\end{array}$ \\
\hline Total & $33 \cdot 7$ & $39 \cdot 0$ & $40 \cdot 6$ \\
\hline Percentage recovery & $97.1 \%$ & $102 \%$ & $92.3 \%$ \\
\hline
\end{tabular}

Acetate and succinate are known to be common products of carbohydrate fermentation (Wood, I96I). The genus Clostridium can also ferment glutamate to yield $\mathrm{CO}_{2}$, acetate and butyric acid (Barker, 1961). Harrison \& Pirt (1967) reported that large amounts of metabolites from glucose accumulated during the oxygen-limited continuous growth of Aerobacter aerogenes. 
Table 2. Acetate and succinate concentrations in culture medium of $P$. denitrificans under nitrate-, nitrite- or nitrous oxide-limited conditions

Figures in parentheses refer to the ratio of the organic acids to the total amount of glutamate consumed on a molar basis. Culture temperature was $30^{\circ} \mathrm{C}$.

$\begin{array}{cccc}\text { Terminal electron acceptors } & \begin{array}{c}\text { Specific growth rate, } \mu \\ \left(\mathrm{h}^{-1}\right)\end{array} & \begin{array}{c}\text { Acetate production } \\ (\mathrm{mM})\end{array} & \begin{array}{c}\text { Succinate production } \\ (\mathrm{mM})\end{array} \\ \text { Nitrate } & 0.049 & 2.15(27 \%) & 1.76(22 \%) \\ & 0.086 & 2.20(28 \%) & 0.58(7.4 \%) \\ \text { Nitrite } & 0.110 & 2.32(30 \%) & 0.01(0.13 \%) \\ & 0.053 & 1.00(19 \%) & 2.22(42 \%) \\ \text { Nitrous oxide } & 0.075 & 1.25(25 \%) & 0.52(10 \%) \\ & 0.110 & 0.82(19 \%) & 0.21(4.8 \%) \\ & 0.057 & 0.97(11 \%) & 0.64(7.6 \%) \\ & 0.089 & 0.87(15 \%) & 0.61(10 \%) \\ & 0.107 & 0.48(9.1 \%) & 0.09(1.7 \%)\end{array}$

From a study of the TCA cycle enzymes and inhibitor experiments, Foget \& Pichinoty (1965) concluded that the TCA cycle is fully operative in the denitrifying bacterium, Micrococcus denitrificans, under denitrifying conditions. This is probably true also of $P$. stutzeri (Spangler \& Gilmour, 1966). The operation of the TCA cycle in our strain of $P$. denitrificans is suggested by the complete oxidation of glutamate under glutamate-limited denitrifying conditions (Koike \& Hattori, I975). The molar composition of the products observed in the present experiment was distinct from that of the fermentation products of glutamate in Clostridium. It is unlikely that the accumulation of metabolites under denitrifying conditions is caused by the fermentative degradation of glutamate. Glutamate oxidation in $P$. denitrificans, in the presence of excess glutamate, may proceed at a rate much higher than that of electron flow through the respiration system when the supply of electron acceptors is limited. Under these circumstances, the concentration of NADH in the cell would be expected to increase. Weitzman \& Jones (I968) showed that citrate synthase of Gram-negative bacteria, including Pseudomonas, is inhibited by NADH. If so this would explain the observed accumulation of acetate.

The identical pattern of carbon distribution among the products under these different conditions strongly suggested that the catabolism of glutamate in this bacterium was not altered by a change of terminal electron acceptors.

\section{Molar growth yield for nitrogenous oxides}

Figure 2 shows the molar growth yields for nitrate, nitrite and nitrous oxide as functions of the specific growth rates. No accumulation of intermediary products of nitrate or nitrite reduction to nitrogen were detected under either nitrate- or nitrite-limited conditions. Nitrogenous oxides were not reduced beyond the nitrogen level when glutamate was the substrate (Koike \& Hattori, 1975). The concentrations of nitrate and nitrite in the culture were always less than $2 \mu \mathrm{M}$. Under $\mathrm{N}_{2} \mathrm{O}$-limited conditions, the $\mathrm{N}_{2} \mathrm{O}$ content of the effluent gas was less than $2 \%$ of that of the inflow gas.

The highest molar growth yield was obtained under nitrate-limited conditions. With nitrite-limitation, it was about $35 \%$ lower. The growth yield for $\mathrm{N}_{2} \mathrm{O}$ was the lowest, being about $65 \%$ lower than that with nitrate-limitation. 


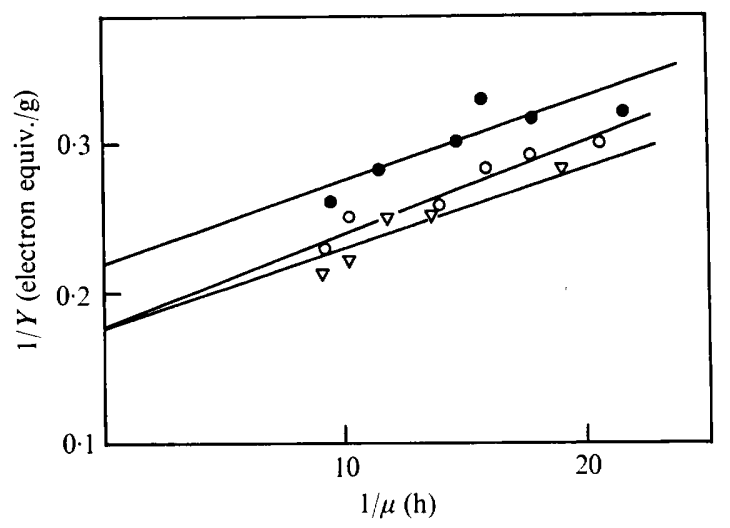

Fig. 3. Double reciprocal plots of $Y$ against $\mu$ in nitrate-, nitrite- or nitrous oxide-limited growth of $P$. denitrificans. Growth yields are expressed on an electron basis. Linear regression analysis was applied to determine $Y_{\max }$ and $m$. $O$, Nitrate limitation; $\nabla$, nitrite limitation; $\bullet$, nitrous oxide limitation.

Table 3. $Y_{\max }$ and maintenance energy coefficients $(m)$ of $P$. denitrificans for nitrate, nitrite and nitrous oxide

Calculated from the data given in Fig. 3.

$\begin{array}{lccc}\text { Limiting substance } & \overbrace{\mathrm{g} / \mathrm{mol}} Y_{\max } & \mathrm{g} / \text { electron equiv. } & \begin{array}{c}10^{-3} \times \text { Maintenance } \\ \text { energy coefficient, } m \\ \text { (electron equiv./g/h) }\end{array} \\ \text { Nitrate } & 28.6 & 5.72 & 6.48 \\ \text { Nitrite } & 16.9 & 5.63 & 4.95 \\ \text { Nitrous oxide } & 8.80 & 4.40 & 5.36\end{array}$

Maintenance energy requirements and maximum growth yields

The catabolic process is closely conjugated with the anabolic process under electron acceptor-limited conditions in this bacterium, because the flow rate of electrons through the respiratory systems of denitrification controls the overall process of bacterial growth (Senez, 1962). The growth yield increased with increase in the supply of terminal electron acceptor or the specific growth rate (Fig. 2).

Maintenance energy requirements $(m)$ and maximum growth yield $\left(Y_{\max }\right)$ under nitrate-, nitrite- and $\mathrm{N}_{2} \mathrm{O}$-limited conditions can be determined from a plot of $\mathrm{I} / Y$ versus $\mathrm{I} / \mu$ (Pirt, 1965) (Fig. 3). This determination was made with respect to the terminal electron acceptors reduced. The $Y_{\max }$ values for nitrate, nitrite and $\mathrm{N}_{2} \mathrm{O}$ were estimated to be $28 \cdot 6,16 \cdot 9$ and $8.8 \mathrm{~g} / \mathrm{mol}$, respectively (Table 3 ). However, the $Y_{\max }$ values expressed on an electron basis were almost identical with each other (Table 3). Values for maintenance energy coefficients were also almost identical and agreed well with those obtained under glutamate-limited conditions in the presence of oxygen or nitrate (Koike \& Hattori, 1975).

\section{DISCUSSION}

There is a controversy as to which step(s) in the sequential reduction of nitrate to nitrogen is associated with phosphorylation in bacterial denitrification. Nitrite reductase of $P$. denitrificans is a soluble enzyme (Iwasaki, Shidara, Suzuki \& Mori, I963), and this suggests that phosphorylation is not coupled with nitrite reduction (Yamanaka, I964). The same conclusion was obtained by Naik \& Nicholas (1966) from ${ }^{32} \mathrm{P}$ experiments using cell-free extracts of $P$. denitrificans. 
On the other hand, the occurrence of phosphorylation coupled with nitrite reduction has been reported in the Iwasaki strain of $P$. denitrificans (Ohnishi \& Mori, 1960; Matsubara, Miyata, Terai \& Mori, I969). In $M$. denitrificans, phosphorylation is associated with nitrite reduction but not with $\mathrm{N}_{2} \mathrm{O}$ reduction (Naik \& Nicholas, 1966). They suggested that only nitrogenous oxides containing at least two atoms of oxygen are effective in phosphate esterification.

Cox \& Payne (1973) found that nitrite and NO reductases of $P$. perfectomarinus are solubilizable, but nitrate and $\mathrm{N}_{2} \mathrm{O}$ reductases are particulate-bound. They inferred that throughout the whole process of denitrification only two steps, the reduction of nitrate to nitrite and the reduction of $\mathrm{N}_{2} \mathrm{O}$ to $\mathrm{N}_{2}$, function as energy-yielding systems.

The data obtained with cell-free systems are sometimes biased by artefacts produced during preparation and do not necessarily reflect the events occurring in vivo. Assessment of energy yield based on growth yield in chemostat cultures is advantageous, because there is no risk of introducing such effects.

In the oxidation of glutamate, ATP would be produced mainly by oxidative phosphorylation coupled to electron transport of denitrification, except for the ATP formation associated with acetate production. One mole of ATP is synthesized per mole of acetate, if acetate is produced via acetyl-CoA. The contribution to energy production associated with acetate production ( $Y_{\text {acetate }}$ ) was estimated, assuming $Y_{\text {ATP }}=10 \mathrm{~g} / \mathrm{mol}$ (Forrest, 1969). The fraction of $Y_{\text {acetate }}$ in the total growth yield was $10 \pm 3 \%(w / w)$. Therefore, the effect of acetate production can be disregarded. Under these circumstances, the $Y_{\max }$ values for nitrate, nitrite and $\mathrm{N}_{2} \mathrm{O}$ can be correlated with energy yields associated with the reduction of these nitrogenous oxides to nitrogen.

The relative energy yields calculated from the data given in Table 3 for reduction of nitrate, nitrite and $\mathrm{N}_{2} \mathrm{O}$ to nitrogen were $5 \cdot 0,3 \cdot 0$ and 0.8 , respectively. These values are proportional to the oxidation number of the nitrogenous oxides: nitrate $(+5)$, nitrite $(+3)$ and $\mathrm{N}_{2} \mathrm{O}(+\mathrm{I})$. We take growth yield per half mole of $\mathrm{N}_{2} \mathrm{O}$, because the $\mathrm{N}_{2} \mathrm{O}$ molecule contains two nitrogen atoms. The reduction of nitrite to $\mathrm{N}_{2} \mathrm{O}$ consists of two consecutive steps: nitrite to NO, and $\mathrm{NO}$ to $\mathrm{N}_{2} \mathrm{O}$ (Payne, 1973). Unfortunately, the growth yield under NO-limitation has not been determined because of technical difficulties. It is therefore uncertain whether phosphorylation is associated with either of these reduction steps, although circumstantial evidence suggests with both. In any event, the present data (Table 3 ) show that phosphorylation is coupled with the reduction of nitrite to $\mathrm{N}_{2} \mathrm{O}$ in our strain of $P$. denitrificans, a finding incompatible with the view presented by Yamanaka (1964), Naik \& Nicholas (1966) and Cox \& Payne (1973) on results of experiments using cell-free systems.

The $Y_{\max }$ values and the maintenance energy coefficients for these nitrogenous oxides are almost identical if expressed on an electron basis (Table 3 ). The extent of coupling of electron transport chains with phosphorylation, or the number of phosphorylation sites in the electron transport chain in each step of the denitrification sequence, seem to be identical. The energy yield of $P$. denitrificans associated with denitrification is approximately half that with aerobic respiration on an electron basis (Koike \& Hattori, 1975). We therefore conclude that the number of sites of oxidative phosphorylation in the electron transport systems associated each step of denitrification is about half that in the electron transport system associated with with oxygen respiration. This view is consistent with the observation that, in extracts of $M$. denitrificans, ATP synthesis coupled with oxygen is about $70 \%$ more efficient than that coupled with nitrate reduction to nitrite (John \& Whatley, 1970). 
The authors thank Dr H. Minato, National Institute of Animal Health, for his help in performing the chromatographic analysis of organic acids. This work was supported by a grant from the Ministry of Education, Japan.

\section{REFERENCES}

Barbaree, J. M. \& Payne, W. J. (1967). Products of denitrification by a marine bacterium as revealed by gas chromatography. Marine Biology I, I36-1 39 .

BARKER, H. A. (I96I). Fermentation of nitrogenous organic compounds. In The Bacteria, vol. 2, pp. I5I207. Edited by I. C. Gunsalus and R. Y. Stanier. New York: Academic Press.

BENDSCHNEIDER, K. \& RoBinson, R. J. (1952). A new spectrophotometric method for the determination of nitrite in sea water. Journal of Marine Research II, 87-96.

Cox, C. D. \& PAYNE, W. J. (1973). Separation of soluble denitrifying enzymes and cytochromes from Pseudomonas perfectomarinus. Canadian Journal of Microbiology 19, 86I-872.

Foget, P. \& Pichinoty, F. (1965). Le cycle tricarboxylique chez une bactérie denitrifiante obligatoire. Annales de l'Institut Pasteur 108, 364-377.

ForRest, W. W. (1969). Energetic aspects of microbial growth. Symposia of the Society for General Microbiology $19,65-86$.

Harrison, D. E. F. \& PIRT, S. J. (1967). The influence of dissolved oxygen concentration on the respiration and glucose metabolism of Klebsiella aerogenes during growth. Journal of General Microbiology 46, 193-2II.

Iwasaki, H., Shidara, S., Suzuki, H. \& Mori, T. (1963). Studies on denitrification. VII. Further purification and properties of denitrifying enzyme. Journal of Biochemistry 53, 299-303.

John, P. \& Whatley, F. R. (1970). Oxidative phosphorylation coupled to oxygen uptake and nitrate reduction in Micrococcus denitrificans. Biochimica et biophysica acta 216, 342-352.

Kodama, T., Shimada, K. \& Mori, T. (1969). Studies on anaerobic biphasic growth of a denitrifying bacterium, Pseudomonas stutzeri. Plant and Cell Physiology 10, 855-865.

KoIKE, I. (1975). The energetics of nitrate respiration in Pseudomonas denitrificans and Serratia marcescens. Ph.D. thesis, University of Tokyo, Japan.

KoIKe, I. \& HATtORI, A. (1975). Growth yield of a denitrifying bacterium, Pseudomonas denitrificans, under aerobic and denitrifying conditions. Journal of General Microbiology 88, I-10.

Matsubara, T. (197I). Studies on denitrification. XIII. Some properties of the $\mathrm{N}_{2} \mathrm{O}$-anaerobically grown cell. Journal of Biochemistry 69, 99I-I00I.

Matsubara, T., Miyata, M., Terai, K. \& Mori, T. (1969). Denitrifying process in Pseudomonas denitrificans. Soil and Micro-organisms II, 45-54 (in Japanese).

Matsubara, T. \& Mori, T. (I968). Studies on denitrification. IX. Nitrous oxide, its production and reduction to nitrogen. Journal of Biochemistry 64, 849-86I.

MiYata, M. \& Mori, T. (I968). Studies on denitrification. VIII. Production of nitric oxide by denitrifying reaction in the presence of tetramethyl-p-phenylenediamine. Journal of Biochemistry 64, 849-861.

- NaIK, M. S. \& Nicholas, D. J. D. (1966). Phosphorylation associated with nitrate and nitrite reduction in Micrococcus denitrificans and Pseudomonas denitrificans. Biochimica et biophysica acta 113, 490-497.

OHNISHI, T. (1963). Oxidative phosphorylation coupled with nitrate respiration with cell-free extracts of Pseudomonas denitrificans. Journal of Biochemistry 53, 71-79.

OHNISHI, T. \& MORI, T. (1960). Oxidative phosphorylation coupled with denitrification in intact cell systems. Journal of Biochemistry 48, 406-4I I.

Pascal, M. C., Pichinoty, F. \& Bruno, V. (1965). Sur les lactate-deshyrogenases d'une bactérie denitrifiante. Biochimica et biophysica acta 99, 543-546.

PAYNE, W. J. (1973). Reduction of nitrogenous oxides by micro-organisms. Bacteriological Reviews 37, 409-452.

Payne, W. J., Riley, P. S. \& Cox, C. D. (197I). Separate nitrite, nitric oxide and nitrous oxide reducing fractions from Pseudomonas perfectomarinus. Journal of Bacteriology 106, 356-361.

PIRT, S. J. (1965). The maintenance energy of bacteria in growing cultures. Proceedings of the Royal Society B I63, 224-23I.

SENEZ, J. C. (1962). Some considerations on the energetics of bacterial growth. Bacteriological Reviews 26, 95-107.

SPANGLER, W. J. \& Gilmour, C. M. (1966). Biochemistry of nitrate respiration in Pseudomonas stutzeri. I. Aerobic and nitrate respiration routes of carbohydrate catabolism. Journal of Bacteriology 9r, 245-250. 
Weitzman, P. D. J. \& Jones, D. (1968). Regulation of citrate synthase and microbial taxonomy. Nature, London 219, 270-272.

Wood, E. D., Armstrong, F. A. \& Richards, F. A. (1967). Determination of nitrate in the sea water by cadmium copper reduction to nitrite. Journal of the Marine Biological Association of the United Kingdom 47, 23-3I.

Wood, W. A. (196I). Fermentation of carbohydrates and other carbon compounds. In The Bacteria, vol. 2, pp. 59-149. Edited by I. C. Gunsalus and R. Y. Stanier. New York: Academic Press.

YAmANAKA, T. (I964). Identity of Pseudomonas cytochrome oxidase with Pseudomonas nitrite reductase. Nature, London 204, 253-255.

YamanaKA, T., Ota, A. \& OKUnUKI, K. (1962). Oxidative phosphorylation. I. Evidence for phosphorylation coupled with nitrate reduction in a cell-free extract of Pseudomonas aeruginosa. Journal of Biochemistry 5r, 253-258. 